\title{
BEMUTATÓ MEGJEGYZÉSEK
}

\section{HAJDÚ ZOLTÁN}

Minden nemzetközi és hazai folyóirat életében megszokott, hogy a ,rendes” számok mellett ,,speciális”, ,külön”, avagy „tematikus” számot állít össze, illetve jelentet meg. A TÉT is többször és sikeresen élt már ezzel a lehetöséggel.

Minden, a ,rendes üzemmenettől” eltéró számnak külön üzenete van, hiszen az adott időszakban a társadalmat, avagy annak jelentős csoportjait érintő kérdéseket tüz napirendre. Amikor a Tisztelt Olvasó kézbe veszi a valamilyen szempontból egyedi számot, felteszi magának a kérdést, hogy milyen megközelítésben olvassa, értékelje, viszonyuljon hozzá. A legfontosabb talán annak tudatosítása, hogy semmilyen tematikus szám nem egységes monográfia, az egyes tanulmányok szerzője, avagy szerzői ,saját bỏrüket viszik a vásárra”, így szükségszerủen eltérỏ megközelítések, különbözö fogalmai apparátusok, egyedi értékítéletek jelennek meg az adott folyóirat tematikus számában.

A TÉT város-rehabilitációval foglalkozó tematikus száma minden tekintetben időszerü és fontos kérdést ,jár körül”, vizsgál, elemez. Az államszocialista korszak, illetve a rendszerváltás után eltelt másfél évtizedes időszak más-más okból és módon, de elhanyagolta városok egyes, sok esetben a belső területek állapotának a megörzését, lényegi javítását.

A tematikus szám bemutatásakor nem megyek bele a részletes elemzésekbe, hiszen a három „felbérelt” szakértő kollégám ezt fogja elvégezni, így elsősorban néhány általános kérdés felvetésére szorítkozom.

A tematikus szám egyes tanulmányainak szerzői a téma kiemelkedő magyar kutatói, (geográfusok, közgazdászok, szociológusok, jogászok, építészek) de láthatóan önálló megközelítéssel éltek, elkülönülő kategóriarendszerrel (fogalmi apparátussal) elemeztek. A megjelenő tanulmányok eltérő vállalásai (elméleti, gyakorlati, fejlesztési stb. megközelítések) jelentős részben indokolják is ezeket a kủlönbségeket, de nem minden tekintetben teszik érthetövé azokat.

A legfontosabb (közös) alapkérdés az, hogy miért kell rehabilitálni a várost (városrészt, negyedet, kerületet, blokkot stb.), s milyen értékek megörzése elkerülhetetlen, s milyen korábbi (19. századi beépített értékeket) lehet, illetve kell meghaladni. A mai városhasználó elvárásai nem teljesen azonosíthatóak az adott településrész eredeti lakosságának korabeli igényeivel. (Ez az objektív eltérés szükségszerüen vezet el konfliktusokhoz.)

A város-rehabilitáció így egyszerre szól a múlt megörzéséröl, meghaladásáról, valamint a jövőbeni elképzelések, törekvések fizikai megtestesüléséröl. A rehabilitáció során meg kell válaszolni azt a kérdést, hogy milyen jellegü, karakterü, funkciójú, hangulatú várost akarunk látni, illetve formálni.

A tematikus szám alapvetően Budapestre koncentrál, s kiegészítő jelleggel jelennek meg egyéb telepiilések (Györ, Pécs) városrekonstrukciós, város-rehabilitációs kérdései. 
A valóságos helyzetnek megfelel az, hogy a város-rehabilitáció legnagyobb kihívását Budapest jelenti, hiszen a főváros belső kerületei, valamint az ún. „barnaövezet”, alvagy „rozsda-övezet” olyan jelentös területeket ölel fel, melyek megújítása nélkül a fôváros csak szürkeségét őrizheti meg.

Budapest esetében egyszerre kell számolni a világörökség részévé vált területek állapotának javításával, a belváros 19. századi építészeti kultúrája értékes részének megórzésével, valamint az új funkciót kapó területek hosszabb távú beillesztésének átfogó gondjával.

A rész és egész kapcsolata, dialektikája elemi módon veti fel a kérdést, hogy a városrehabilitációs folyamatban megőrizhetô-e Budapest mint egész sajátos, egyedi hangulata, részeinek belsö intimitása, a polgárok azonosulása a folyamatokkal, illetve a folyamatok végeredményével.

A város-rehabilitáció egyszerre építészeti, müszaki, gazdasági, társadalmi, szociális, esztétikai stb. kérdések halmazát veti fel, s akkor még nem beszéltünk az új kihívásoknak való megfelelés kényszeréröl, nevezetesen, ha Budapest helyt akar állni a nemzetközi és különösen a közép-európai városversenyben, akkor milyen módon kell ehhez igazítani a város egyes területeinek funkcióját, építészeti megoldásait, képét.

A városlakók „élhetô város” fogalma sokféle elemet hordoz, söt városrészenként, társadalmi csoportként is erôsen változik. A várospolitika egyik nagy kihívása az, hogyan tudja biztosítani azt, hogy a város-rehabilitáció után a „lakható és élhető tér" elfogadható legyen az érintett polgárok döntő többsége számára.

A volt NDK hatalmas lakótelepeinek lakosai - a múszaki és erkölcsi megújítás ellenére - ha tehetik, „menekülnek” a telepi élettől. Az itteni lakótelepek problémái és sorsa (megkezdődött egyes telepek teljes lebontása) azt mutatja, hogy a rendszerváltás, társadalmi jövőkép-váltás után a várospolitikának új módon kell felkészülnie a házgyári lakótelepek, lakások felújításárá. 